\title{
一電解質量の影響一
}

\author{
山内 慎 ${ }^{\circ}$, 杉浦 公彦, 淀 忠勝 (大阪府立高専), 谷本 一美 (産総研)
}

\section{Visualization of Electrolyte Volatile Phenomenon in MCFC}

-Effect of Electrolyte Filled-

\author{
Makoto YAMAUCHI, Kimihiko SUGIURA, Tadakatsu YODO \\ and Kazumi TANIMOTO
}

\begin{abstract}
Volatilizing of molten carbonate as electrolyte in Molten Carbonate Fuel Cell (MCFC) is one of degradation factors. The Volatilization of the molten carbonate brings the cross-leak and the corrosion of the metallic materials. Moreover, the piping blockage caused by solidification of the volatile chemical species in piping will be happened at lowering temperature. Especially, since the reforming catalysts filled to the anode channel in Direct Internal Reforming Molten Carbonate Fuel Cells (DIR-MCFC) are polluted by volatile species from the molten carbonate, volatilizing of the molten carbonate is an important issue. However, the behavior of molten carbonate volatile issue has been not elucidated, since the volatilization volume is too small amount to analyze them. Last symposium, we informed that at anode side, amount of volatilized particle was increasing with increasing current density. Although volatilization phenomenon was observed at cathode side, there was no relationship between amount of volatilized particle and current density. The volatile chemical species from anode and cathode were potassium rich composition.
\end{abstract}

Keywords : MCFC, Electrolyte volatile phenomenon, In-situ observation

\section{1. はじめに}

地球環境問題にかかる温室効果ガスの削減への対応お よび国際情勢の不安定さが増す中で, エネルギーセキュリ ティ確保の観点から，石油，石炭，天然ガスなどの多様な 化石然料源を利用でき，高効率なエネルギー変換技術であ る溶融炭酸塩形燃料電池 (MCFC) は, その実用化が強く 望まれ，その開発が鋭意取り組まれてきた，MCFC 発電 技術は, 平成 16 年度までの技術開発で $1000 \mathrm{~kW}$ 級システ ムの実証を行い, $700 \mathrm{~kW}$ 級の分散型発電システムの実用 化開発研究を行った。この実用化開発研究の中では, MCFC 発電システムとして求められる 4 万時間の長期信 頼性を見通すために, その主要な劣化要因であるニッケル 短絡に関しての技術開発を行い, 4 万時間の信頼性の道笳 をつけた，一方，MCFC では発電温度で液体となる溶融 炭酸塩を電解質として用いており，長期に亘る発電中にこ れが電解質板内で損耗あるいは損失し，電池抵抗の増加， 電極での電気化学反応性の低下につながり,その結果とし て電池性能低下を引き起こすことが示されている.この点 から揮発現象にかかる項目も今後寿命に関わる仮題とし
て重要になると考えられる.

そこで本研究では，その中でもこれまでの熱力学データ からその影響が大きくないと考えられていた溶融炭酸塩 電解質の揮発現象に関して, 電極面積 $16 \mathrm{~cm}^{2}$ の単セル電 池を用いて発電電池内部を直接観察してその挙動につい ての検討を進めてきた 1,2)。ここでの実験条件としては揮 発現象が可視化できるように電解質の充填率を通常の電 池運転条件よりも多くしてきた，今回は，充填率を減らし て通常の運転条件とした場合のアノード, カソードの両極 で起こる揮発現象についてそれぞれ検討した。

\section{2. 実験装置および条件}

実験装置の配置を Fig.1 に, 可視化用の発電電池の構造 をFig.2 にそれぞれ示す. 可視化用の単電池は, 可視化対 象とする極での内部可視化のために, 光源入射路と観察空 を取り付けたホルダーを用いた. 光源入射路と観察密が取 り付けられたパイプの内径は $7.6 \mathrm{~mm}$ であるため, 観察対 象のガス流路深さを $10 \mathrm{~mm}$ とした. 通常のガス流路深さ は 3〜 4mm である. 電極表面近傍まで観察するために, 集電板は取り外している.ニッケル系多孔質電極の厚さは $0.4,0.6,0.8(\mathrm{~mm}) の 3$ 種類とした. 通常電極厚みは 
0.8 $(\mathrm{mm})$ である，電解質充填量はほぼ同量とし，電極の厚 みの変化によって電解質充填率を変化させた. 電解質とし $\tau(62+38) \mathrm{mol} \%(\mathrm{Li}+\mathrm{K}) / \mathrm{CO}_{3}$ 混合塩を用いた。電解質充填 率が高いほど, 電極-電解質-ガスの三相界面は, ほぼ電極 表面に移行するため揮発が起こりやすい. これらの電池構 成材料は産業技術総合研究所関西センター内のドライル 一ムで作成した。電池運転温度は $650^{\circ} \mathrm{C}$ と, PID 制御さ れたヒーター板によって一定温度を維持した. セル電圧は データロガーを用いて常時記録した. 供給ガス条件として, アノード極では $70.4 \mathrm{H}_{2} / 17.6 \mathrm{CO}_{2} / 12 \mathrm{H}_{2} \mathrm{O}$, カソード極では $70 \mathrm{air} / 30 \mathrm{CO}_{2}$ とし，ガス利用率は両極ともに $40 \%$ である.

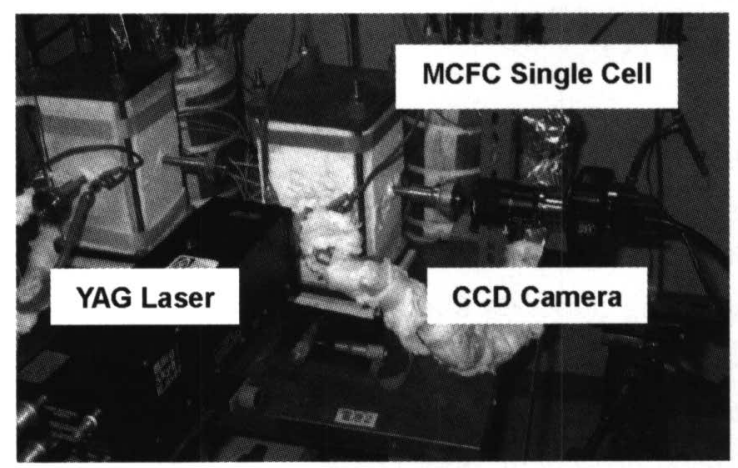

Fig.1 Photograph of experimental apparatus.

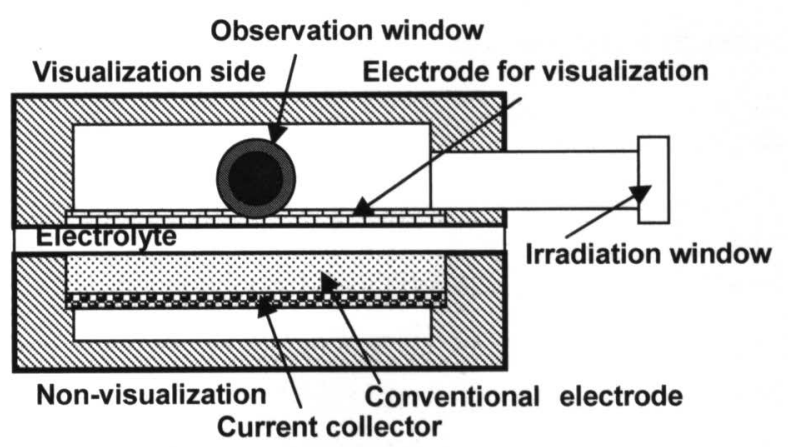

Fig.2 Schematic diagram of MCFC for visualization.

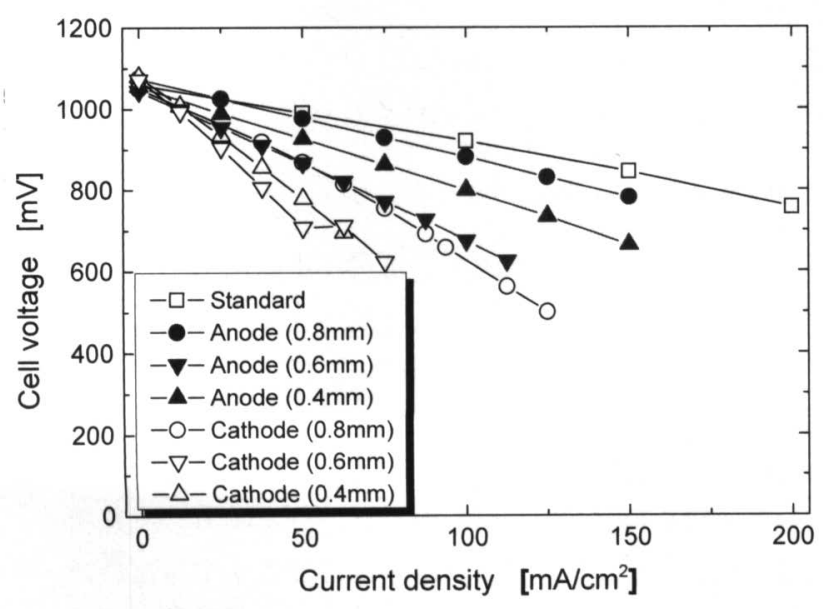

Fig.3 Initial V-I performances of the visualization cells.
発電状態で, Fig.2 の右側の空から YAG-Laser (120mJ) によるパルスシート光を入射し, 電池内部を照らし, 正面 の空から CCD ディジタルビデオカメラ(DVC-1312CL, $1300 \times 1030$ pixels, $11 \mathrm{fps})$ によ画像を記録した.

標準条件における初期の電池性能（V-I 特性）を Fig.3 に示す. 本図より，アノード電極を通常の厚み $(0.8 \mathrm{~mm})$ とすることによって, V-I 特性は従来の電池性能とほぼ一 致しており, 電極厚みが薄くなるにつれて性能が悪くなる ことがわかる. また, カソード電極を可視化する場合には アノード極の場合と比べて電池性能が悪い. 通常, 電極部 材は集電板を用いることによって部材そのものの熱変形 を抑制する効果をもたしているが, 可視化電池ではこれを 用いていないため, アノード電極に比べてやわらかいカソ ード電極は, 電極そのものが熱変形し, 集電部からのズレ が生じたことによる.とくに, 電極厚みが薄い場合にその 傾向が顕著である.

\section{3. アノード極側の電解質揮発現象}

Fig.4 に電流密度を変化させたときのアノード電極近傍 の画像を示す.ここで, アノード電極厚みは $0.4 \mathrm{~mm}$ で, 電極は画像の下部にあり, 図の左側よりガスが流入し, 右 側より排気されている，本図より，揮発物は OCV（無負 荷）の条件では確認できない. 電流密度が増加するにした がって, 揮発物はガス入口側から出口側に向かってベルト 状になって流れ，その量は増加している. MCFC 発電温 度では溶融炭酸塩は液体であるから, その飛沫の飛散現象 であると考えられるが, 画像から固体状に観察されること から以下のように考えた.

アノード側では, 負極反応で水と炭酸ガスが生成される 環境にある. 炭酸リチウム/カリウムの混合炭酸塩が, 発 電条件で分解あるいは揮発して水酸化物を生成し気相に 達する. この際, 我々の研究1)で水酸化物の揮発量は, 力 リウム, ナトリウム, リチウムの順に小さくなり, 水酸化 カリウムは他のものより 1 桁揮発量が多いことがわかっ ている. そのため, 気相では水酸化カリウムが多量にあり, これが反応生成した炭酸ガスと反応して炭酸カリウムが 微粒子状で観察されていると考えた.この仮説を確認する ために, PTFE 製メンブランフィルター(気孔径: $3 \mu \mathrm{m}$ )を ガス排気側に設置して 3 日間発電を行い, 3 日経過後, フ イルターを取り出しこれを $1 \mathrm{~mol} / \mathrm{cm}^{3}$ の塩酸で洗い出して, イオンクロマトグラフにより同定し, 組成面でカリウム成 分が多い結果 $(\mathrm{Li} / \mathrm{K}=15 / 85 \mathrm{~mol} \%)$ が得られた.これより, 電池反応によって電解質の主成分である水酸化カリウム が揮発していることが確認された.

Fig.5 に示すように, 電解質充填率を減らすと, 電極厚 み $0.6 \mathrm{~mm}$ の場合にはガス入口側にわずかな揮発物が確認 できるが, 通常厚みの $0.8 \mathrm{~mm}$ ではほとんど確認できない. つまり, 電解質の充填率が少ない分, 電極細孔内で揮発し 
た電解質は電極内で捕獲されるため, 画像計測で観測でき る揮発物がガス流路まで上がってくることはほとんどな いことを意味している. しかし, わずかな揮発でも長期に 亘る運転によって積算量は大きくなり, 電池性能低下を引 き起こすことになる.

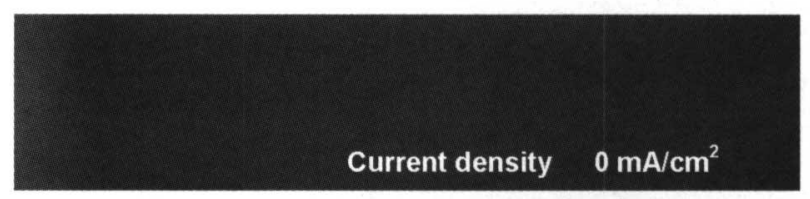

Current density $37.5 \mathrm{~mA} / \mathrm{cm}^{2}$
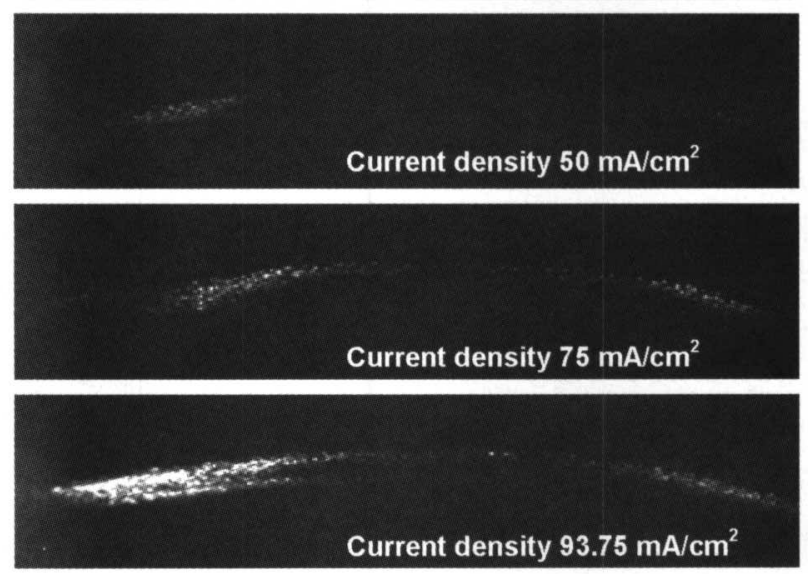

Fig.4 Measurement image in the anode channel when the current density is changed.
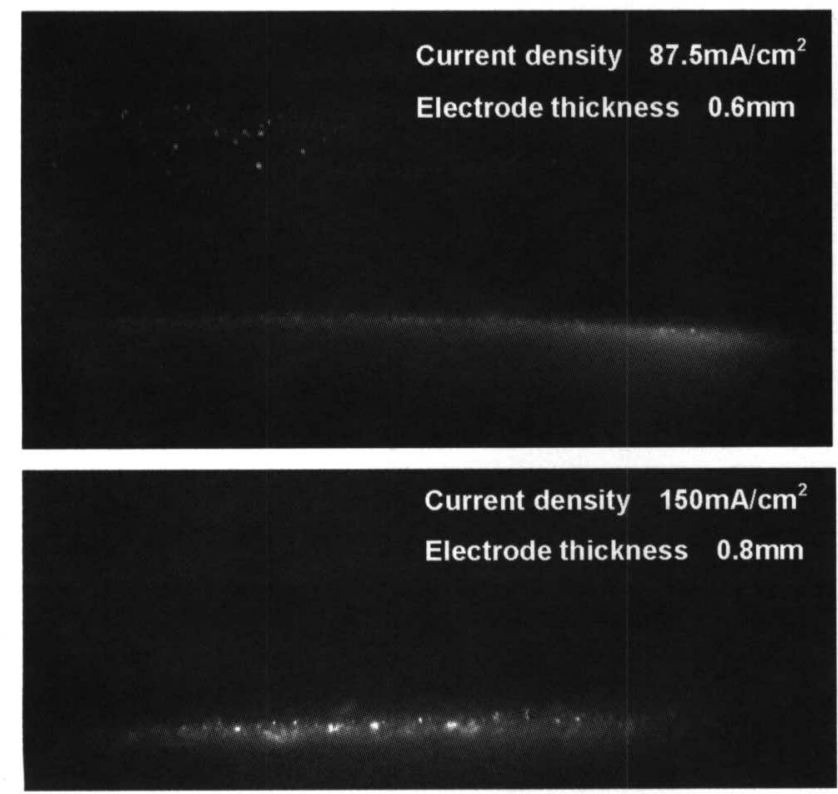

Fig.5 Measurement image in the anode channel when the amount of the electrolyte filled increases.

\section{4. カソード極側の電解質揮発現象}

MCFC のカソード極側は反応ガスの消費系であるため, 生成物とともに電解質が揮発することはない，また，供給 ガスも $70 \mathrm{Air} / 30 \mathrm{CO}_{2}$ であることから $\mathrm{H}_{2} \mathrm{O}$ による電解質の 水酸化物も生じず, 電解質の揮発現象は生じていないとさ れている，しかし，カソード出口に設置されている熱交換 器において電解質成分による流路閉塞現象が生じている. そこで, アノード極同様の方法により, カソード電極近傍 を可視化した. カソード側の撮影画像を Fig.6 に示す. 図 の中央に白く太く見えるものが電極である，本図より，白 色飛散物が電極表面上方 $0.4 \mathrm{~mm}$ の位置にガスの流れに沿 って分布していることがわかる.この飛散物は電流密度を 変えても変化が見られず, OCV 条件においても見られる. これより,この揮発物が電池反応に伴う現象ではないと判 断できる. そこで, アノード極同様に揮発物を採取して分
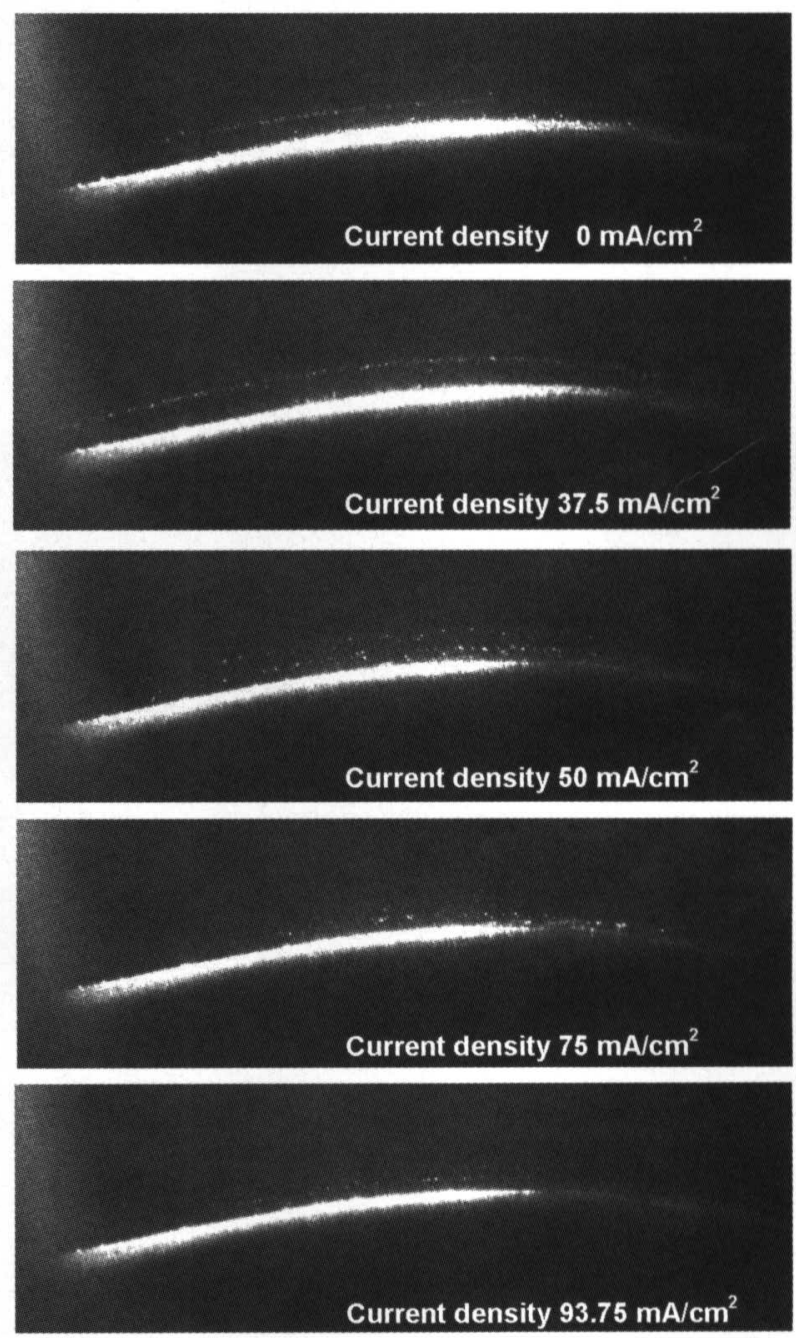

Fig.6 Measurement image in the cathode channel when the current density is changed. 
析したところ，組成面で電解質に近い組成 $(\mathrm{Li} / \mathrm{K}=28 / 72$ $\mathrm{mol} \%)$ 淂られ, 電極に過剩に充填した電解質の飛沫が飛 散していることがわかった，電極の厚みを $0.6 \mathrm{~mm}, 0.8 \mathrm{~mm}$ として, 電解質充填率を低くすると揮発物は確認できなか った.

一方, 先述のとおり, カソード電極材はやわらかいので, 電池運転に伴って電極そのものが湾曲しはじめ, 時間とと もに湾曲の程度が大きくなり, 最終的に Fig.7 に示すよう に電極表面に割れが生じ, 割れ部よりガスの噴出による電 解質の噴霧が見られた. いわゆる両極が通じるクロスリー ク現象である. 上述の飛散物は電解質が過剩に充填された 電極が湾曲することで電解質自身が浮き出て, ガスの流れ によって運ばれた可能性がある。そこで，電解質が過剩に 充填された電極厚みが $0.4 \mathrm{~mm}$ のものに，通常の電池のよ うに集電板を取り付けて電極の湾曲を抑えて可視化した. その結果，Fig.8 に示すように飛散物は本可視化手法では 観察されなかった。これより, 本実験で可視化できた飛散 物は電極の湾曲により可視化できたものであるといえる， しかし，長時間運転を目指して電解質を過剩に充填すると， 電極内に充填されなかった電解質がミストとなって飛散 し, その結果, 後段の熱交換器を閉塞させる問題を引き起 こす可能性があることが示された. 本可視化手法では観察

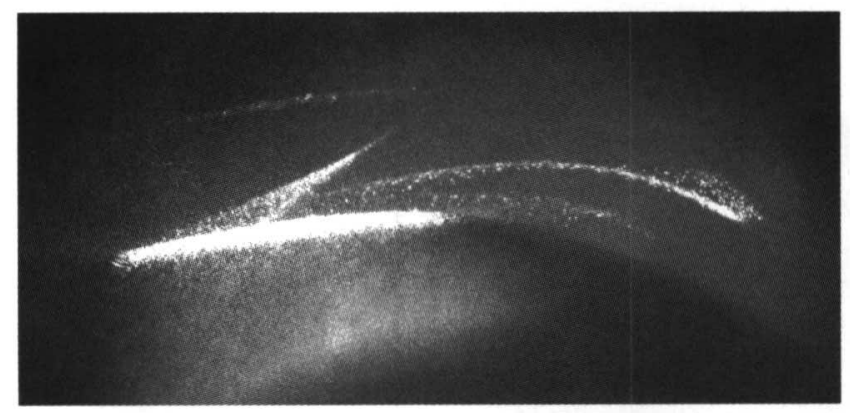

Fig. 7 Measurement image of the electrolyte jet from the crack of electrode to the gas channel.
できない程度の電解質自身の揮発も生じている可能性は ある.これが，長期に亘る運転によって蓄積されるものと 考える、

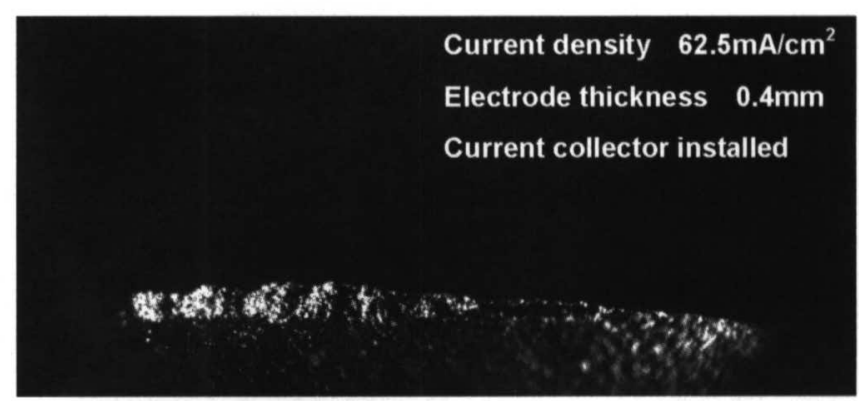

Fig.8 A current collector is installed to prevent the electrode from cracking.

\section{5. まとめ}

$\mathrm{MCFC}$ 発電システムの耐久性向上の課題として, 従来 注目されてなかった溶融炭酸塩電解質の揮発状態を実電 池内での可視化により，この現象の解明を行った.

（1）アノード側では電流密度の増加に伴って電解質の主 成分である水酸化カリウムが揮発することを確認し た.

（2） カソード側では電解質が電極表面上に存在すること によって電解質そのものが飛散することを確認した。

\section{参 考 文 献}

1) K. SUGIURA, M. YAMAUCHI, K. TANIMOTO, Y. YOSHITANI, Evaluation of volatile behavior and the volatilization volume of molten salt in DIR-MCFC by using the image measurement technique, Journal of Power Sources Vol. 145, (2005. 8), pp. 199-205.

2）淀忠勝, 大川英晃, 山内慎, 杉浦公彦, 谷本一美, 溶融炭 酸塩形燃料電池における電解質揮発現象の画像計測, 第 33 回可視化情報シンポジウム講演論文集 Vol. 25 Suppl. No. 1 (2005. 7), pp. 35-38. 